Article

\title{
Investigating Young Consumers' Purchasing Intention of Green Housing in China
}

\author{
Lin Zhang ${ }^{1,2, *}$, Liwen Chen ${ }^{1, *}$, Zezhou $\mathrm{Wu}^{3}{ }^{(1)}$, Sizhen Zhang ${ }^{2}$ and Huanbin Song ${ }^{2}$ \\ 1 School of Economics and Management, Hebei University of Technology, 5340 Xiping Road, Beichen District, \\ Tianjin 300401, China \\ 2 School of Management Engineering, Shandong Jianzhu University, 1000 Fengming Road, Licheng District, \\ Jinan 250101, China; sizhen678@163.com (S.Z.); HBSongedu@126.com (H.S.) \\ 3 Department of Construction Management and Real Estate, Shenzhen University, Shenzhen 518060, China; \\ wuzezhou@szu.edu.cn \\ * Correspondence: zhanglin2007@sdjzu.edu.cn (L.Z.); Lwchen@hebut.edu.cn (L.C.); \\ Tel.: +86-531-8636-1579 (L.Z.); +86-22-6043-5165 (L.C.)
}

Received: 1 February 2018; Accepted: 30 March 2018; Published: 2 April 2018

\begin{abstract}
The issues of energy crisis, environmental degradation, and climate change present a severe challenge to the sustainable development in China. The development of green building (GB) is considered one of the most popular strategies toward a sustainable construction industry. Apart from advanced green technologies, consumers' purchasing intention toward green housing $(\mathrm{GH})$ plays a crucial role in the large-scale promotion of GB. However, which determinants significantly affect consumers' purchasing intention remain unclear, especially for the young generation in developing countries. This study attempts to investigate young consumers' purchasing intention of GH in China. On the basis of extended theory of planned behavior (TPB), seven constructs are identified, and nine hypotheses are proposed. A total of 241 responses were collected from the questionnaire survey, and structural equation modeling was employed to test the proposed hypotheses. Governmental incentives are affirmed to be the most important determinant, followed by consumers' attitude toward behavior and subjective norm. Perceived behavioral control is an insignificant determinant for young consumers to purchase GH. In addition, subjective knowledge has an indirect effect through attitude toward behavior. Environmental concern also confirms an indirect effect through attitude toward behavior and subjective norm toward purchasing intention, respectively. Thus, the government is implied to play a crucial role in GH promotion at this stage.
\end{abstract}

Keywords: sustainable consumerism; green housing; environmental concern; theory of planned behavior; young consumers; purchasing intention

\section{Introduction}

With the rapid urbanization and industrialization in the past decades, China has become one of the largest energy consumers and $\mathrm{CO}_{2}$ emitters worldwide. The country constructed 1.6-2.0 billion $\mathrm{m}^{2}$ of buildings each year, accounting for nearly $40 \%$ of the total new buildings in the world [1]. Adopting green building (GB) strategies in the construction industry can contribute to a reduced $\mathrm{CO}_{2}$ emission and energy dependence on fossil fuels [2,3], which is also an inevitable choice to meet the need for environmental protection and sustainable development [4]. However, the amount of GB in China is only 5\% of the total new buildings [5], which is far less than that of the conventional counterpart. Although the GB market in China is still in the initial stage [6], the Chinese government has been responsive to the sustainable development in the construction industry by formulating GB codes and regulations and evaluation standards, providing financial and nonfinancial incentives [7]. 
This started with issuing a clear certification named, "Evaluation Standard for Green Building" in 2007 to explain what is GB by the Chinese Ministry of Housing and Urban-Rural Development (MOHURD), which updated the latest version in 2014. This certification is mostly employed in residential or public buildings and contains six certification categories, including land-saving and outdoor environment, water conservation and utilization of water resources, energy saving and utilization, material saving and utilization, indoor environmental quality, and operation and management [8]. In our research, green housing $(\mathrm{GH})$ refers to urban residential buildings that have been awarded the certification of the Chinese green building label. Moreover, suitable databases for GB technology, products and materials were also established by the central or local authorities, such as the "Technical Guidance for Green Building Promotion" published by MOHURD in 2005. Additionally, government has issued different degrees of strictness of policies, consisting of voluntary scheme instrument, economic incentives and mandatory administration [9]. For instance, "Green Building Action Initiatives" which were published by the Chinese General Office of the State Council in 2013, stipulated that real estate developers were encouraged to voluntarily build GH communities and provided economic subsidies with them, while affordable housing and buildings financed by government must attain the certification of GB from 2014. Currently, Chinese government serves as the biggest motivator, advocator $[10,11]$ to promote GB.

In March 2017, MOHURD initiated building energy-saving and green building development planning in 13th five-year (2016-2020), one of which named "redoubling amount of green buildings". That is, compared with actual practices in the 12th Five-Year Plan (2011-2015), attempts are made to achieve the target that over 2 billion $\mathrm{m}^{2}$ of new GBs, and over $50 \%$ of new buildings are awarded GB certification during the 13th Five-Year Plan. From 5\% to 50\%, a very large gap exists between the actual practices and ambitious target. Thus, in the context of preliminary stage of GH with the features of government-led GH development path, research of GBs on large-scale promotion must be conducted.

Different types of stakeholders have participated in the GB implementation. For instance, Chan, et al. [12] explored the critical factors influencing GB investment from the perspective of building designers in Hong Kong and Singapore and from the developers [13,14]. Moreover, earlier studies $[6,15,16]$ affirmed that clients and customers or tenants were identified to have utmost influence in GB promotion. Sustainable goals achieved in the construction industry will largely depend on substantial consumer demands [17]. Only if the purchasers are willing to pay extra for GH will developers supply the latter to the market [18]. Other research also determined the vital role of consumers in large-scale GB promotion. For instance, Darko, et al. [19] reviewed the research on the drivers of GB and reported that the demand and willingness of customers eventually determined the extent of GB development. In addition, Liu, et al. [20] reported that the biggest problem in promoting GH that required resolution was the low level of market demand for GH. Therefore, research on consumers' purchasing intention is essential to promote $\mathrm{GH}$ at a significant scale.

Driven by sustainable development worldwide, consumers have gradually changed their views and interests in the products they buy [21]. Specifically, green consumerism behavior is complex and influenced by diverse factors, especially for the green products with large expenditures, such as housing and cars. Thus far, which determinants significantly affect consumers' purchasing intention and the relationship between these determinants and purchasing intention of GH remain unclear. Thus, the present research employs the social psychological model to investigate consumers' purchasing intention of GH in the Chinese context. Theory of planned behavior (TPB) is adopted, which is considered the most popular theoretical model to explain determinants and antecedents of purchasing intention. This theory further attempts to include three additional constructs (i.e., subjective knowledge, environmental concern, and governmental incentives) to extend the theoretical framework. Subjective knowledge [20], environmental concern [22], and governmental incentives [18] were considered equally important in the green consumerism area.

Previous research conducted on GB consumption was focused on the general consumers $[17,18,23,24]$. To our knowledge, limited research was conducted on the special consumer group, especially neglecting the opinions and attitudes of youth. The current study 
emphasizes on the youth because of their crucial role in the development of GH. On the one hand, the number of youth accounts for a large proportion of the total population. According to the data from the Chinese Statistical Bureau in 2016, the amount of young group aged 15-29, accounted for the $21.36 \%$ of the total population. On the other hand, the youth have a strong demand in housing consumerism. In the context of Chinese culture and social norms, every couple should purchase a house for dwelling before marriage. Thus, most of them will likely become potential consumers in the housing market. Nevertheless, no research exists on the purchasing intention of GH for young consumers in China.

To remedy this research gap, the article aims to investigate the major determinants influencing the young consumers' purchasing intention of GH in China. Three reasons explain China's status as an effective laboratory for research. First, China contains the largest construction market worldwide [25]. Achieving sustainability in the Chinese construction industry will prominently reduce the adverse global impact on climate change, built environment, and human health. Consequently, the research findings can meet the pressing need to promote GH on a large scale by the Chinese government. Second, China is one of the representatives of the developing countries experiencing the same puzzling conflict between economic development and environmental degradation. Thus, the study findings can offer valuable references and experiences for policy-makers and other organizations in other developing countries. Third, most of the previous studies focused on GH purchasing failed to consider young consumers. Understanding their purchasing intention can contribute to bridge this research gap. Furthermore, stipulating suitable policy strategies by policy-makers would be crucial in guiding the GH implementation.

\section{Literature Review and Hypothesis Development}

\subsection{TPB}

TPB was proposed by Ajzen in 1985, which is one of the most extensively used behavior theories. TPB is also one of the most popular theories to analyze individuals' intention and behavior [26]. The TPB framework determines behavioral intention by attitude toward behavior (AB), subjective norm (SN), and perceived behavioral control (PBC) [27]. Correspondingly, Figure 1 illustrates the TPB framework. Generally, people who favorably evaluate the behavior sense pressure from the expectations of relevant others. Moreover, possessing the ability to adopt certain behaviors likely establishes high behavioral intentions.

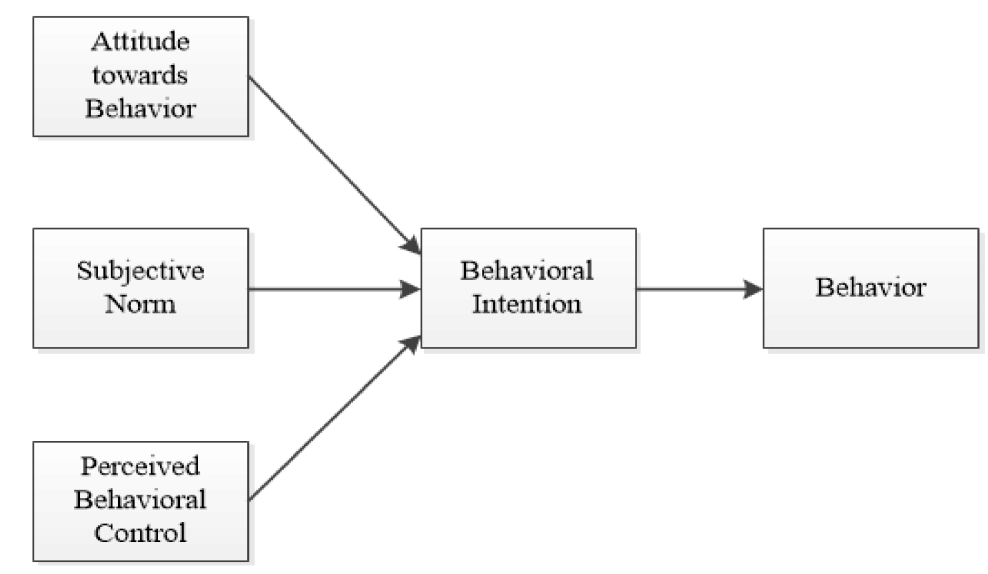

Figure 1. Framework for theory of planned behavior.

To date, TPB has been applied to predict consumers' intention and behavior in a wide range of areas, including electric vehicles [28,29], green hotels [30-32], and energy conservation [33,34]. TPB was also regarded as a highly powerful model in explaining the environment friendly behavior [35] 
or environmentally-sustainable products [36]. For instance, Maichum, Parichatnon, and Peng [26] investigated the purchase intentions of Thai consumers for green products and validated that attitude, subjective norm, and perceived behavioral control had significant positive influences on the purchase intention for green products. According to the above discussion, we submit the following hypotheses.

Hypothesis 1 (H1): Attitude toward purchasing GH has a positive effect on intention to purchase GH.

Hypothesis 2 (H2): Subjective norm has a positive effect on intention to purchase GH.

Hypothesis 3 (H3): Perceived behavioral control has a positive effect on intention to purchase GH.

\subsection{Inclusion of Additional Constructs in TPB}

Young consumers have certain distinct features compared with other groups. Most of them were born in single-child families. Moreover, parents usually aid them with housing purchasing, which can significantly advance their purchasing ability. In addition, obtaining higher education prompted their concern for the environment [37]. Exploring young consumers' purchasing intention of GH is essential to design sustainable incentive strategies [38] because they are the future consumers and future of society [39]. Moreover, these young people are also the innovators in the sustainability market and prone to attempt new products, such as green hotel visits [40].

Hence, for the measurement of their purchasing intention of $\mathrm{GH}$, additional constructs should be considered to extend the basic TPB model, namely, subjective knowledge (SK), governmental incentives (GI), and environmental concern (EC). Thus, the initial theoretical model is established (see Figure 2). A total of seven constructs were involved, including attitude toward purchasing GH (ATT), subjective norm (SN), perceived behavioral control (PBC), purchasing intention (PI), subjective knowledge (SK), governmental incentives (GI), and environmental concern (EC). Additional constructs are explained as follows.

H5

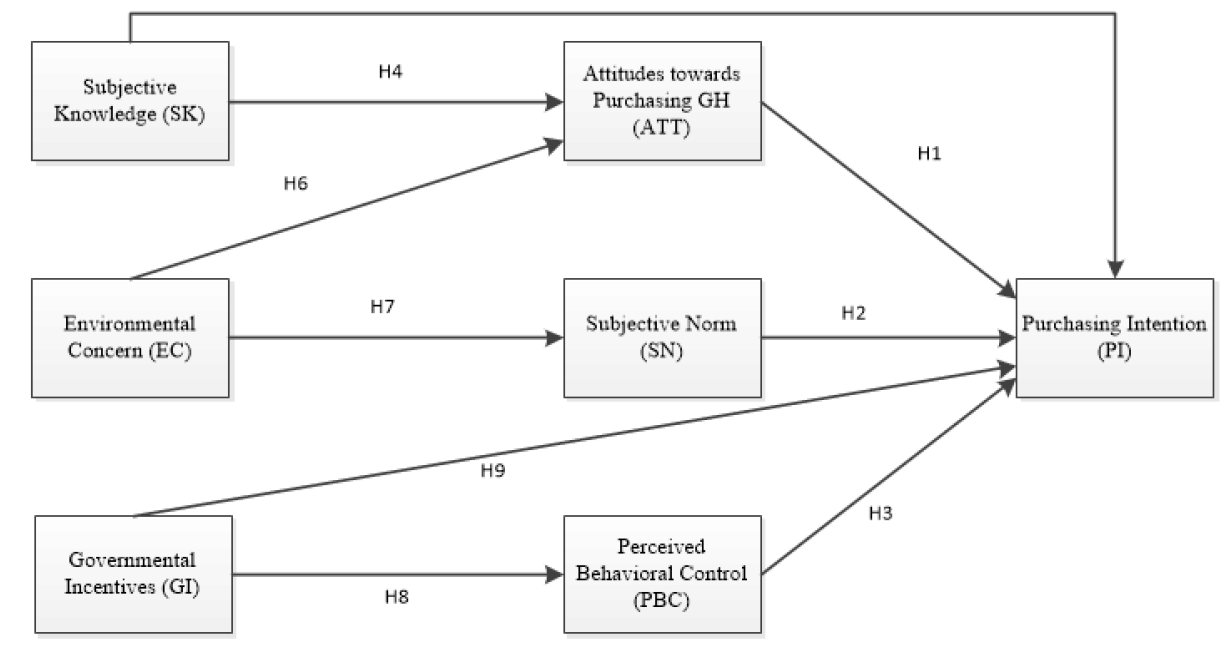

Figure 2. Proposed research framework.

Subjective knowledge (SK) is included in extended theory of planned behavior because various studies have concluded the importance of knowledge on the purchasing intention of green products. For instance, Liu et al. [20] reported that lacking subjective knowledge among surveyed residents served as psychological barriers to their acceptance of green-labeled residential buildings. From the 
literature review, Darko and Chan [15] corroborated that the lack of knowledge was the most identified barriers in GB adoption. Echoing these findings, Reddy and Painuly [41] expressed that the lack of adequate awareness on the costs and benefits of sustainable energy technologies among stakeholders may lower the interest of the latter to promote the former. Therefore, if young consumers possess further knowledge on $\mathrm{GH}$, then they may likely hold positive attitude toward the latter, which will, in turn, directly arouse additional purchase intention. Thus, the following hypotheses are suggested:

Hypothesis 4 (H4): Young consumers' subjective knowledge of GH has a positive effect on attitude toward GH.

Hypothesis 5 (H5): Young consumers' subjective knowledge of GH has a positive effect on purchasing intention.

Environmental concern is one of the important sustainability variables in green marketing literature defined as "the consumers' emotional involvement regarding different environmental matters" [42]. Environmental concern is also a critical factor in the consumer decision-making process [43]. Earlier research within the environmental domains, such as in the green energy brand [44] and green-purchasing behavior [42], has verified that environmental concern directly motivated pro-environmental purchase intention or behavior. In line with the similar findings, Mostafa [45] asserted that environmental concern was one of the major variables that influenced consumers' attitudes and purchase intention of green products. Thus, young consumers with high levels of environmental concern will likely purchase GH. Thus, the above discussion leads to the following hypotheses:

Hypothesis 6 (H6): Young consumers' environmental concern of GH has a positive effect on attitudes toward GH.

Hypothesis 7 (H7): Young consumers' environmental concern of GH has a positive effect on subjective norm.

Governmental incentives are contained for the following reasons: Generally, the government plays an important and leading role in GB promotion. In the GH market, different reasons have led to market failure, such as externality and asymmetric information [18], which may induce the additional transaction cost [46]. Incremental cost may also incur in the process of GH development. Profit-driven developers will definitely transfer additional costs to consumers. Provided that no economic compensation exists for the consumers, most of them will not voluntarily purchase the GH. Therefore, governmental incentives are essential to promote GB development [47]. Several studies have concluded that governmental incentives significantly affected the green consumerism behavior. For instance, Darko, Zhang, and Chan's [19] research expressed that incentive schemes are ranked 5th among the 64 drivers identified from the literature review. Thus, through the effective incentive approaches, such as economic subsidies, tax deduction and exemption, and soft loan preferential policies, young consumers will have strong affordability to purchase GH. This possible scenario can also improve the level of purchasing intention. Therefore, the following hypotheses can be proposed.

Hypothesis 8 (H8): Governmental incentives have a positive effect on perceived behavioral control.

Hypothesis 9 (H9): Governmental incentives have a positive effect on intention to purchase GH.

\section{Research Methodology}

\subsection{Design of the Questionnaire}

A questionnaire survey was conducted for data collection to accomplish the objective of this study. Measurement variables for each construct in the study are either selected or adapted from the relevant studies. The items employed to measure the seven constructs are rated using a five-point Likert's scale ( strongly disagree $=1$; disagree $=2 ;$ neutral $=3$; agree $=4$; strongly agree $=5$ ) . 
Prior to the formal survey, expert interviews were conducted to improve the reliability and validity of the draft measurement scales in the Chinese context. Six participants were involved in the interview, including two professors and two researchers familiar with the related research topics: one marketing manager employed in a known real estate company with nearly 10 years of GH-developing experiences and one construction manager from a large AEC company, who has participated in several GB-certified projects in China. After the consideration of their recommendations, improvements were made by adding and deleting details in the survey questions. In addition, the wording in the questions was also refined to achieve the simplicity and ease of understanding. Finally, Table 1 establishes the measurement scales in the formal questionnaire for data collection.

Table 1. Measurement scales in the formal questionnaire.

\begin{tabular}{|c|c|}
\hline Constructs and Measuring Items & Sources \\
\hline $\begin{array}{l}\text { Attitude toward purchasing GH } \\
\text { ATT1: I think that purchasing GH is favorable. } \\
\text { ATT2: I think that purchasing GH is a good idea. } \\
\text { ATT3: I think that purchasing GH is safe. }\end{array}$ & {$[26,48]$} \\
\hline $\begin{array}{l}\text { Subjective norm } \\
\text { SN1: My family thinks that I should purchase GH over conventional housing. } \\
\text { SN2: My close friends think that I should purchase GH over conventional housing. } \\
\text { SN3: Most people who are important to me think that I should purchase GH over } \\
\text { conventional housing. }\end{array}$ & {$[26,49]$} \\
\hline $\begin{array}{l}\text { Perceived behavioral control } \\
\text { PBC1: I am confident that I can purchase GH over conventional housing when I want. } \\
\text { PBC2: I see myself capable of purchasing GH in the future. } \\
\text { PBC3: I have the resources, time, and willingness to purchase GH. }\end{array}$ & {$[50,51]$} \\
\hline $\begin{array}{l}\text { Subjective knowledge } \\
\text { SK1: I know what the evaluation of GH is. } \\
\text { SK2: I know why we need to develop GH. } \\
\text { SK3: I know the advantages of GH over conventional housing. }\end{array}$ & [20] \\
\hline $\begin{array}{l}\text { Environmental concern } \\
\text { EC1: Mankind is severely abusing the environment. } \\
\text { EC2: Limits to growth beyond which our industrialized society cannot expand emerge. } \\
\text { EC3: Humans must live in harmony with nature to survive. }\end{array}$ & {$[44,52]$} \\
\hline $\begin{array}{l}\text { Governmental incentives } \\
\text { GI1: Government supplies tax incentives to consumers for GH purchasing. } \\
\text { GI2: Government supplies direct grants to consumers for GH purchasing. } \\
\text { GI3: Government supplies a soft loan incentive to consumers for GH purchasing. }\end{array}$ & {$[11,53-55]$} \\
\hline $\begin{array}{l}\text { Purchase intention for GH } \\
\text { PI1: I would like to purchase GH. } \\
\text { PI2: I would like to live in GH. } \\
\text { PI3: I would like to recommend GH to my family and friends. }\end{array}$ & {$[20]$} \\
\hline
\end{tabular}

\subsection{Data Collection}

A survey was conducted in the urban city of Shandong Province in East China, which is famous for the birthplace of Confucius. According to the following two reasons, the residents of Shandong Province were chosen as the respondents. At the end of 2017, the city ranked 4 th in the number of GBs at the province level in China and was subsequently awarded with 214 GBs and 18 LEED projects [56].The profound influence of the Chinese traditional culture has prompted young consumers' enthusiasm to purchase an independent housing for marriage.

Questionnaires were distributed via two channels from June 2017 to the middle of August 2017. The first channel was an online survey and was sent to the link of the online survey through social media channels (e.g., QQ and WeChat) to potential housing purchasers among the 18-30 year-old 
age group dwelling in Shandong Province. The snowball sampling method was employed to invite the respondents to distribute the questionnaires to their friends, relatives, and colleagues, which can economically ensure the large number of questionnaires. The second channel was a field survey conducted by six trained investigators. Details on the aim of the survey and concept of GH were told to potential respondents. They were chosen from real estate sales offices in Jinan City, which is the capital of Shandong Province. The respondents completed the written questionnaires after they agreed to participate in this research. Combined with two channels, a total of 510 questionnaires were distributed. Subsequently, completed responses numbered 326 (a response rate of 59.3\%). Data screening process was then conducted to guarantee the validity of the responses. The questionnaires containing blanks or incomplete answers and conflicting reverse question responses were excluded, retaining 241 questionnaires for the final analysis. As suggested by Kline [57], the sample size should be a minimum of 10 cases per item. Given the 21 items in the study, a minimum of 210 cases are required. Thus, 241 cases of the final sample satisfy this requirement.

\subsection{Data Analysis}

Structural equation modeling (SEM) using the analysis of moment structures (AMOS 21) software developed by IBM corporation was employed to analyze the collected data. SEM is an extensively used multivariate analysis technique in psychological and behavioral studies. The model involves latent and manifest variables. The measurement model in SEM can be employed to test the reliability and validity of the scale, while the structure model is a tool to analyze the hypotheses. We also conducted the confirmatory factor analysis (CFA) to evaluate the reliability and validity of the proposed theoretical model.

\section{Results}

\subsection{Descriptive Statistics}

The basic demographics of the respondents are as follows. The total number of respondents comprises 128 males (53.11\%) and 113 females (46.89\%). The highest proportion of the respondents fell into the $18-25$ year-old age group $(66.80 \%)$, followed by the $26-30$ year-old age group $(33.20 \%)$. Nearly $52.70 \%$ of the respondents earned a bachelor's degree, and $13.28 \%$ of the respondents had a master's degree or above. The household monthly income (RMB) of the respondents was reported as follows: respondents earning between 5001 and 10,000 account for $29.51 \%$, those earning below 3000 account for $21.72 \%$, and those earning above 30,000 account for $2.87 \%$. The mean value of PI1 "I would like to purchase GH is 3.93", nearly 4.097 of the item named by "I plan to purchase more green products rather than normal products," which was expressed in the research of Maichum, Parichatnon, and Peng [26] for green products among Thai consumers. This finding also affirms the high level of willingness to pay for GH among the Chinese youth.

\subsection{Measurement Model: Reliability and Validity}

Through confirmatory factor analysis (CFA), the study aims to identify whether the proposed theoretical framework meets the standards of reliability and validity (see results in Table 2). Cronbach's $\alpha$ is utilized to measure internal consistency among items. All of them are greater than 0.70 , meeting the recommended value of 0.7 [58]. Therefore, the value obtained confirms the adequate reliability of all constructs. Construct reliability is measured using composite reliability (CR). The CR scores range from 0.7787 to 0.9154 , expressing good convergent validity [59]. Convergent validity is further measured using factor loading and average variance extracted. All of the factor loadings are close to or above the acceptable level of 0.6 , as suggested by Chin, et al. [60]. The average variance extracted for the seven measures is higher than 0.5 , showing convergent validity at the construct level [59]. 
Table 2. Reliability and validity of the constructs.

\begin{tabular}{|c|c|c|c|c|c|}
\hline Construct & Item & Cronbach's $\alpha$ & $\begin{array}{l}\text { Standardized } \\
\text { Factor Loading }\end{array}$ & $\begin{array}{l}\text { Composite } \\
\text { Reliability }\end{array}$ & $\begin{array}{c}\text { Average } \\
\text { Variance } \\
\text { Extracted }\end{array}$ \\
\hline $\begin{array}{c}\text { Attitude toward } \\
\text { purchasing GH (ATT) }\end{array}$ & $\begin{array}{l}\text { ATT1 } \\
\text { ATT2 } \\
\text { ATT3 }\end{array}$ & 0.867 & $\begin{array}{l}0.77 \\
0.91 \\
0.80\end{array}$ & 0.8675 & 0.687 \\
\hline Subjective norm (SN) & $\begin{array}{l}\text { SN1 } \\
\text { SN2 } \\
\text { SN3 }\end{array}$ & 0.764 & $\begin{array}{l}0.81 \\
0.81 \\
0.57\end{array}$ & 0.7787 & 0.5457 \\
\hline $\begin{array}{l}\text { Perceived behavioral } \\
\text { control (PBC) }\end{array}$ & $\begin{array}{l}\text { PBC1 } \\
\text { PBC2 } \\
\text { PBC3 }\end{array}$ & 0.772 & $\begin{array}{l}0.69 \\
0.91 \\
0.63\end{array}$ & 0.7929 & 0.567 \\
\hline $\begin{array}{l}\text { Environmental } \\
\text { concerns (EC) }\end{array}$ & $\begin{array}{l}\text { EC1 } \\
\text { EC2 } \\
\text { EC3 }\end{array}$ & 0.874 & $\begin{array}{l}0.81 \\
0.80 \\
0.91\end{array}$ & 0.8788 & 0.7081 \\
\hline $\begin{array}{l}\text { Subjective knowledge } \\
\text { (SK) }\end{array}$ & $\begin{array}{l}\text { SK1 } \\
\text { SK2 } \\
\text { SK3 }\end{array}$ & 0.841 & $\begin{array}{l}0.79 \\
0.81 \\
0.78\end{array}$ & 0.836 & 0.6295 \\
\hline $\begin{array}{l}\text { Governmental } \\
\text { incentives (GI) }\end{array}$ & $\begin{array}{l}\text { GI1 } \\
\text { GI2 } \\
\text { GI3 }\end{array}$ & 0.912 & $\begin{array}{l}0.93 \\
0.80 \\
0.92\end{array}$ & 0.9154 & 0.7838 \\
\hline $\begin{array}{l}\text { Purchase intention for } \\
\text { green housing }(\mathrm{PI})\end{array}$ & $\begin{array}{l}\text { PI1 } \\
\text { PI2 } \\
\text { PI3 }\end{array}$ & 0.874 & $\begin{array}{l}0.83 \\
0.85 \\
0.80\end{array}$ & 0.8664 & 0.6838 \\
\hline
\end{tabular}

Table 3 provides the value of discriminant validity. A factor correlation below 0.8 represents adequate discriminant validity [61]. The square root of AVE for each construct was higher than its correlations with other constructs, which can represent adequate discriminant validity [60]. Overall, the theoretical model indicates adequate validity and reliability.

Table 3. Correlation between the constructs

\begin{tabular}{cccccccc}
\hline & ATT & SN & PBC & SK & EC & GI & PI \\
\hline ATT & $\mathbf{0 . 8 2 9}$ & & & & & & \\
SN & 0.198 & $\mathbf{0 . 7 3 9}$ & & & & & \\
PBC & 0.074 & 0.055 & $\mathbf{0 . 7 5 3}$ & & & & \\
SK & 0.387 & 0.263 & 0.177 & $\mathbf{0 . 7 9 3}$ & & & \\
EC & 0.415 & 0.476 & 0.116 & 0.551 & $\mathbf{0 . 8 4 1}$ & & \\
GI & 0.301 & 0.225 & 0.246 & 0.720 & 0.472 & $\mathbf{0 . 8 8 5}$ & \\
PI & 0.421 & 0.298 & 0.231 & 0.801 & 0.443 & 0.770 & $\mathbf{0 . 8 2 7}$ \\
\hline
\end{tabular}

\subsection{Structural Model: Goodness of Fit Statistics, Modeling Comparison, and Hypothesis Testing}

The structural model was conducted using AMOS 22.0 to test for the goodness of fit statistics. Initially, structural analysis yielded a contradicting result with the TPB model, which showed that all three of the constructs, such as ATT, $\mathrm{SN}$, and PBC did not significantly influence the purchasing intention (PI). Interpreting this finding in real life seems difficult. In the initial CFA, the value of CFA fit indices represented an adequate model fit (chi-square $=395.909$, chi-square $/$ [degree of freedom] $=2.249$, goodness of fit index $[\mathrm{GFI}]=0.871$, comparative fit index $[\mathrm{CFI}]=0.929$, root mean square error of approximation [RMSEA] $=0.072$ ). After applying the modification indices and deleting the path of subjective knowledge to purchasing intention, CFA was conducted again on the modified theoretical 
framework. Subsequently, the value expressed a better model fit (chi-square $=407.494$, chi-square $/$ [degree of freedom $]=2.302, \mathrm{GFI}=0.866, \mathrm{CFI}=0.925$, RMSEA $=0.074$ ). Table 4 expresses the GFIs.

Table 4. Measurement model fit indices.

\begin{tabular}{ccc}
\hline Fit Indices & Criteria & Indicators \\
\hline Chi-square & & 407.494 \\
Chi-square/(degree of freedom) & $<5$ acceptable; $<3$ good & 2.302 \\
Goodness of fit index (GFI) & $>0.8$ acceptable; $>0.9$ good & 0.866 \\
Adjusted goodness of fit index (AGFI) & $>0.8$ acceptable; $>0.9$ good & 0.826 \\
Relative fit index (RFI) & $>0.9$ & 0.853 \\
Normed fit index (NFI) & $>0.9$ & 0.876 \\
Comparative fit index (CFI) & $>0.9$ & 0.925 \\
Root mean square error of approximation (RMSEA) & $<0.1$ acceptable; $>0.08$ good & 0.074 \\
Root mean square residual (RMR) & & 0.105 \\
\hline
\end{tabular}

Table 5 presents the results of the structural model. Moreover, the standardized path coefficient expressed positive effects among the constructs in the structural model. Seven of the nine hypotheses were supported. The variables of TPB, attitudes $(\beta=0.14, \mathrm{t}=2.685, p=0.007)$, and subjective norm ( $\beta=0.11, t=2.162, p=0.031$ ) significantly influenced young consumers' purchasing intention of $\mathrm{GH}$; whereas the perceived behavioral control $(\beta=0.04, \mathrm{t}=0.911, p=0.362)$ showed no significant influences on GH purchasing intention. Therefore, $\mathrm{H} 1$ and $\mathrm{H} 2$ were supported. Conversely, $\mathrm{H} 3$ was not supported.

Table 5. Hypothesis results for the structural model.

\begin{tabular}{|c|c|c|c|c|c|}
\hline Hypothesis & $\begin{array}{c}\text { Path } \\
\text { Correlation }\end{array}$ & $\begin{array}{l}\text { Standardized Path } \\
\text { Coefficient }\end{array}$ & T-Value & $p$ & Results \\
\hline $\mathrm{H} 1$ & ATT-PI & 0.14 & 2.685 & $0.007^{* *}$ & Supported \\
\hline $\mathrm{H} 2$ & SN-PI & 0.11 & 2.162 & 0.031 * & Supported \\
\hline H3 & PBC-PI & 0.04 & 0.911 & 0.362 & Not supported \\
\hline $\mathrm{H} 4$ & SK-ATT & 0.23 & 2.622 & 0.009 ** & Supported \\
\hline H6 & EC-ATT & 0.29 & 3.39 & $* * *$ & Supported \\
\hline H7 & EC-SN & 0.48 & 6.340 & $* * *$ & Supported \\
\hline $\mathrm{H} 8$ & GI-PBC & 0.25 & 3.302 & $* * *$ & Supported \\
\hline H9 & GI-PI & 0.69 & 10.982 & $* * *$ & Supported \\
\hline
\end{tabular}

The additional constructs included in the TPB, namely, subjective knowledge $(\beta=0.23, t=2.622$, $p=0.009$ ), were significantly related to attitude toward purchasing GH. Thus, $\mathrm{H} 4$ was supported. Although subjective knowledge had no direct influence on purchasing intention of $\mathrm{GH}$, it also expressed indirect effects on purchasing intention through ATT. Moreover, environmental concern $(\beta=0.29$, $\left.\mathrm{t}=3.39, p={ }^{* * *}\right)$ confirmed a positive influence on ATT, and EC $\left(\beta=0.48, \mathrm{t}=6.34, p={ }^{* * *}\right)$ also had a significant positive effect on SN. Thus, H6 and H7 were supported. Governmental incentives $(\beta=0.25$, $\mathrm{t}=3.302, p={ }^{* * *}$ ) reported significant positive effect on PBC. Alternately, governmental incentives $\left(\beta=0.69, \mathrm{t}=10.982, p={ }^{* * *}\right)$ also had a direct and significant positive effect on purchasing intention. Thus, both $\mathrm{H} 8$ and $\mathrm{H} 9$ were supported. Figure 3 demonstrates the proposed theoretical model, along with the $\beta$ value. 


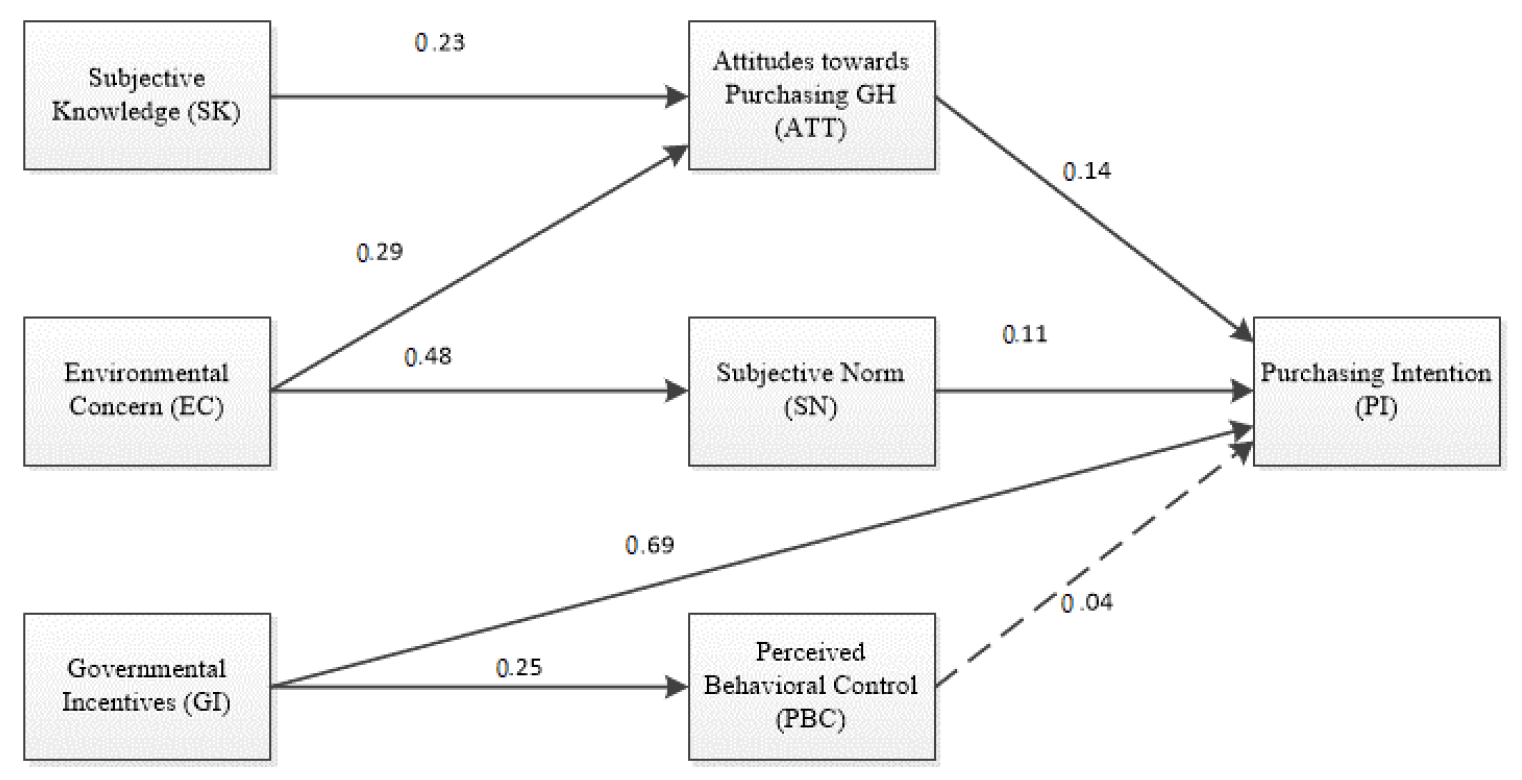

Figure 3. Results of the research model.

\section{Discussion}

Governmental incentives were indicated to have the most significant determinant influencing young consumers' (aged 18-30 years old) purchasing intention of GH, followed by ATT and SN. However, $\mathrm{PBC}$ was affirmed to have no influence on the purchase intention of GH. In addition, purchasing intention is indirectly influenced by subjective knowledge, as well as environmental concern through ATT and SN, respectively (see Figure 3).

Attitude toward purchasing GH and subjective norm had a significant influence on purchasing intention, which is consistent with the findings in extant studies [26,62]. The findings validate the importance of attitude and subjective norm in the context of GH purchasing intention for the Chinese youth. However, an unsupported $\mathrm{H} 3$ is unexpected. The vast majority of studies proved that perceived behavioral control had a significant positive influence on behavioral intention [27], such as in green hotel visiting [40], energy-efficient household appliances [63], and green purchase behavior [64]. Only few studies have concluded similar results [65]. We speculate that this phenomenon is associated with the current social norm of housing consumerism in China. On the one hand, every couple should purchase a house before getting married; on the other hand, with the rapid progress of urbanization, the housing price is dramatically growing every year. Purchasing housing only by themselves is extremely difficult for young consumers. Most of the parents, especially those of the bridegroom, actually assist, using considerable funds to purchase housing. Therefore, the perceived behavioral control of youth has little influence on the purchasing intention of GH.

As for additional constructs, governmental incentives had the strongest influence on purchasing intention. Thus, the government can be concluded to play a crucial role in guiding young consumers' purchase intention of GH. After all, the development of GH in China is still in the initial stage. Through governmental economic incentives, young consumers can be awarded additional economic benefits to offset the high price premium of GH, thereby substantially motivating them to purchase GH. Echoing similar findings from [66,67], an increasing demand can be stimulated by economic benefits. Thus, to attain the ambitious targets of promoting GH on a significant scale, government should formulate different portfolios of economic incentives in guiding the consumers to purchase GH. In addition, different incentive strategies were reported to impose different influences on purchasing intention. Three items were involved in the latent variable of governmental incentives, consisting of tax incentives, direct grants, and soft loan incentives. From the value of standardized factor loading, the tax incentive (0.93) had the most significant influence, followed by soft loan incentive (0.92), 
and lastly, direct grants (0.80). Thus, young consumers easily accept tax and soft loan incentives possibly because of the less grants provided by the government for purchasing $\mathrm{GH}$. In Shandong Province, the housing buyers can be respectively subsidized 15 yuan, 30 yuan, and 50 yuan per square meter for purchasing the residential buildings awarded by one-star, two-star, and three-star certifications. The subsidies are far less than the soaring housing price, from which reached up to 16,000 yuan per square meter in 2018 [68]. Soft loans seem attractive to young consumers. For instance, in Anhui Province located in the east of China, a financial institution can supply the GH buyers with preferential loan interest rate, which is $0.5 \%$ lower than the basic interest rate [69]. Accordingly, this governmental incentives significantly improve the consumers' willingness to pay for GB. To gain accurate understanding on the role of government incentives in the GH market, we invited five experts for telephone interviews. The interviews aim to collect their evaluation of the results, especially for the government incentives. Most of them agreed that government incentives played a critical role in the purchasing intention of consumers, as well as the willingness to nurture developers in China. Currently, the GH market is in its infant stage. Consumers cannot enjoy the benefits of GH before or when they paid for them. Therefore, the consumers were skeptical regarding the benefits of GH in the long term. One consensus opinion of experts is that achieving an efficient market via governmental incentives may require a long time because of unclear benefits achieved in operation phase. Presently, the government-led GH development path is appropriate, with similar findings in [70]. Nevertheless, these incentive strategies heavily depend on financial funds. Private firms can be invited to participate in promoting GH. For instance, public-private partnerships are proposed because they could address limited governmental funds, and vitalize GH market. Property management companies are one of the best cooperators, who can supply economic subsidies for the potential GH purchasers. In GH operation stage, these subsidies can be paid back from the benefits of energy-saving, water-saving and low maintenance costs. Thus, win-win partnerships are achieved among GH purchasers, government, and private investors.

Furthermore, subjective knowledge was affirmed to have indirect influence on the purchasing intention of GH through ATT, which is not entirely consistent with the findings of Liu et al. [20]. This finding may be partly owing to the different resources of the respondents. Compared with youth of Shandong Province aged 18-30 years old in our study, Liu et al. [20] focused on the general consumers in urban Tianjin City, China. Referring to the common findings of subjective knowledge concluded in these two studies, most of the young consumers in China can be inferred to possess inadequate knowledge or information of GH. Existing studies also affirmed that insufficient knowledge, education, or experiences of potential consumers primarily restrict GB implementation [15]. Provided the need to acquire further knowledge on $\mathrm{GH}$, young consumers will gradually express positive attitudes toward purchasing $\mathrm{GH}$, which will consequently result in purchasing intention of GH. Environmental concern was also proven to have an indirect relationship with purchasing intention through ATT and SN. The mean value of environmental concern is up to 3.98, which validates that Chinese young consumers are concerned of related environmental issues. A high environmental concern can contribute to increase the tendency for purchasing intention of GH. This finding is in line with previous studies in other countries [44,71]. In the future, young consumers will be the major purchasing driver in the GH market. Thus, the government should formulate a proper strategic planning to improve environmental awareness or concern via education in schools, enterprise training, and social propaganda.

\section{Conclusions}

This study aims to investigate the young consumers' purchasing intention of GH in the Chinese context. In the study, subjective knowledge, governmental incentives, and environmental concern are included as the antecedents of attitudes toward purchasing $\mathrm{GH}$, subjective norm, and perceived behavioral control. The findings have proven the robust and predictive power of the proposed theoretical framework. The proposed model and measurement scales were also confirmed to be suitable for the study. Young consumers' intention to purchase GH can be predicted directly or 
indirectly by ATT, SN and SK, GI, and EC. Overall, GI directly had the most influence on Chinese youth's purchasing intention, followed by ATT, and lastly SN. In addition, subjective knowledge had an indirect influence through ATT. Environmental concern can also indirectly affect the purchasing intention of GH through ATT and SN. Nevertheless, perceived behavioral control confirmed no significant influence on the purchasing intention of $\mathrm{GH}$.

A few shortcomings should also be considered in future research. First, the sample size of SEM is insufficient, which only satisfies the stipulated requirement. Therefore, future studies can enlarge the number of respondents and add a diverse demographic population to reflect the actual consumer market. In addition, the existing distinct housing demands require future research to provide further attention to diverse consumers in real estate market segmentation. Similar studies have been conducted in a few developed countries, such as on the green residential retirement project of greying people in Australia [72] and undergraduate students in the USA [73]. Second, respondents in our study are limited to consumers in the metropolis, who may have strong economic capacities. Thus, future research can implement the questionnaire survey in the medium and small regions. Subsequently, future research results can be compared with the current study, which may be valuable for policy-makers. Third, purchase intention in the study is measured and not equal to actual purchase behavior. A gap between the intention and behavior has been determined by [74] in recycling electric appliances and [75] in acceptance of solar energy. Thus, with the development of the GH market, other consumers who recognize the benefits of $\mathrm{GH}$ will then voluntarily purchase $\mathrm{GH}$. Investigating factors may be interesting, such as suitable types of marketing and social network communication to drive demands. Similarly, identifying the most effective government incentive strategies influencing the intention-behavior gap of purchasing GH may be useful in future research. Given that the development of GH in China is still in its initial stage, consumers can only identify the benefits of GH from the reported pilot project rather than real-world experiences. With an increasing number of GH in the market, a market approach becomes efficient in encouraging the development of GH. Future research can further explore the relationship between purchasing behavior and operating cost savings, comfort, and potential resale value in the mature market.

Acknowledgments: This work was financially supported by the National Social Science Foundation of China (grant number 14BJY060), Shandong Province Social Science Foundation of China (grant number 17CGLJ12), Jinan Social Science Foundation of China (grant number JNSK18DS12), and the National Science Foundation of China (grant number 71403150). The authors would like to thank all those who contributed to the interviews and reviewed the manuscript.

Author Contributions: The paper was conducted by Lin Zhang, Liwen Chen, Zezhou Wu, Sizhen Zhang and Huanbin Song. Liwen Chen contributed to conceive the study. Lin Zhang contributed to design the study and write the paper. Huanbin Song contributed to data collection. Sizhen Zhang contributed to the data analysis. Zezhou Wu contributed to detailed revision of the paper.

Conflicts of Interest: The authors declare no conflict of interest.

\section{References}

1. Zhang, Y.; Wang, J.; Hu, F.; Wang, Y. Comparison of evaluation standards for green building in china, britain, united states. Renew. Sustain. Energy Rev. 2017, 68 Pt 1, 262-271. [CrossRef]

2. Chang, R.-D.; Soebarto, V.; Zhao, Z.-Y.; Zillante, G. Facilitating the transition to sustainable construction: China's policies. J. Clean. Prod. 2016, 131, 534-544. [CrossRef]

3. Hwang, B.-G.; Shan, M.; Phua, H.; Chi, S. An exploratory analysis of risks in green residential building construction projects: The case of singapore. Sustainability 2017, 9, 1116. [CrossRef]

4. Zhang, X. Green real estate development in china: State of art and prospect agenda-A review. Renew. Sustain. Energy Rev. 2015, 47, 1-13. [CrossRef]

5. Zeng, H. Research on Influential Factors of Developing Green Buildings in Real Estate Enterprises; Zhe Jiang University: Zhejiang, China, 2013. (In Chinese)

6. Li, Y.; Yang, L.; He, B.; Zhao, D. Green building in china: Needs great promotion. Sustain. Cities Soc. 2014, 11, 1-6. [CrossRef] 
7. Chan, A.P.C.; Darko, A.; Effah, E.A.; Owusu-Manu, D.G. Barriers affecting the adoption of green building technologies. J. Manag. Eng. 2016, 31, 04016057. [CrossRef]

8. Teng, J.; Zhang, W.; Wu, X.; Zhang, L. Overcoming the barriers for the development of green building certification in china. J. Hous. Built Environ. 2015, 31, 69-92. [CrossRef]

9. Shen, L.; He, B.; Jiao, L.; Song, X.; Zhang, X. Research on the development of main policy instruments for improving building energy-efficiency. J. Clean. Prod. 2016, 112, 1789-1803. [CrossRef]

10. Qian, Q.K.; Chan, E.H.W. Government measures needed to promote building energy efficiency (bee) in china. Facilities 2010, 28, 564-589. [CrossRef]

11. Olubunmi, O.A.; Xia, P.B.; Skitmore, M. Green building incentives: A review. Renew. Sustain. Energy Rev. 2016, 59, 1611-1621. [CrossRef]

12. Chan, E.H.W.; Qian, Q.K.; Lam, P.T.I. The market for green building in developed asian cities-The perspectives of building designers. Energy Policy 2009, 37, 3061-3070. [CrossRef]

13. Deng, Y.; Wu, J. Economic returns to residential green building investment: The developers' perspective. Reg. Sci. Urban Econ. 2014, 47, 35-44. [CrossRef]

14. Qian, Q.K.; Chan, E.H.W.; Choy, L.H.T. How transaction costs affect real estate developers entering into the building energy efficiency (bee) market? Habitat Int. 2013, 37, 138-147. [CrossRef]

15. Darko, A.; Chan, A.P.C. Review of barriers to green building adoption. Sustain. Dev. 2017, 25, 167-179. [CrossRef]

16. Zhao, D.-X.; He, B.-J.; Johnson, C.; Mou, B. Social problems of green buildings: From the humanistic needs to social acceptance. Renew. Sustain. Energy Rev. 2015, 51, 1594-1609. [CrossRef]

17. Hu, H.; Geertman, S.; Hooimeijer, P. The willingness to pay for green apartments: The case of Nanjing, China. Urban Stud. 2014, 51, 3459-3478. [CrossRef]

18. Yau, Y. Eco-labels and willingness-to-pay: A hong kong study. Smart Sustain. Built Environ. 2012, 1, $277-290$. [CrossRef]

19. Darko, A.; Zhang, C.; Chan, A.P.C. Drivers for green building: A review of empirical studies. Habitat Int. 2017, 60, 34-49. [CrossRef]

20. Liu, Y.; Hong, Z.; Zhu, J.; Yan, J.; Qi, J.; Liu, P. Promoting green residential buildings: Residents' environmental attitude, subjective knowledge, and social trust matter. Energy Policy 2018, 112, 152-161. [CrossRef]

21. Chou, Y.-C.; Yang, C.-H.; Lu, C.-H.; Dang, V.; Yang, P.-A. Building criteria for evaluating green project management: An integrated approach of dematel and anp. Sustainability 2017, 9, 740. [CrossRef]

22. Yadav, R.; Pathak, G.S. Young consumers' intention towards buying green products in a developing nation: Extending the theory of planned behavior. J. Clean. Prod. 2016, 135, 732-739. [CrossRef]

23. Chau, C.K.; Tse, M.S.; Chung, K.Y. A choice experiment to estimate the effect of green experience on preferences and willingness-to-pay for green building attributes. Build. Environ. 2010, 45, 2553-2561. [CrossRef]

24. Zalejska-Jonsson, A. Stated wtp and rational wtp: Willingness to pay for green apartments in sweden. Sustain. Cities Soc. 2014, 13, 46-56. [CrossRef]

25. Wu, Z.; Yu, A.T.W.; Shen, L. Investigating the determinants of contractor's construction and demolition waste management behavior in mainland china. Waste Manag. 2017, 60, 290-300. [CrossRef] [PubMed]

26. Maichum, K.; Parichatnon, S.; Peng, K.-C. Application of the extended theory of planned behavior model to investigate purchase intention of green products among thai consumers. Sustainability 2016, 8, 1077. [CrossRef]

27. Ajzen, I. Perceived behavioral control, self-efficacy, locus of control, and the theory of planned behavior. J. Appl. Soc. Psychol. 2002, 32, 665-683. [CrossRef]

28. Moons, I.; De Pelsmacker, P. An extended decomposed theory of planned behaviour to predict the usage intention of the electric car: A multi-group comparison. Sustainability 2015, 7, 6212-6245. [CrossRef]

29. Wang, S.Y.; Fan, J.; Zhao, D.T.; Yang, S.; Fu, Y.G. Predicting consumers' intention to adopt hybrid electric vehicles: Using an extended version of the theory of planned behavior model. Transportation 2016, 43, 123-143. [CrossRef]

30. Han, H.; Hsu, L.-T.; Sheu, C. Application of the theory of planned behavior to green hotel choice: Testing the effect of environmental friendly activities. Tour. Manag. 2010, 31, 325-334. [CrossRef] 
31. Wu, K.-S.; Teng, Y.-M. Applying the extended theory of planned behavior to predict the intention of visiting a green hotel. Afr. J. Bus. Manag. 2011, 5, 7579-7587.

32. Gerpott, T.J.; Paukert, M. Determinants of willingness to pay for smart meters: An empirical analysis of household customers in germany. Energy Policy 2013, 61, 483-495. [CrossRef]

33. Wang, Z.; Zhang, B.; Li, G. Determinants of energy-saving behavioral intention among residents in beijing: Extending the theory of planned behavior. Renew. Sustain. Energy Rev. 2014, 6, 1-17. [CrossRef]

34. Macovei, O.-I. Applying the theory of planned behavior in predicting proenvironmental behaviour: The case of energy conservation. Int. J. Approx. Reason. 2015, 54, 701-716.

35. Bamberg, S. How does environmental concern influence specific environmentally related behaviors? A new answer to an old question. J. Environ. Psychol. 2003, 23, 21-32. [CrossRef]

36. Kumar, B.; Manrai, A.K.; Manrai, L.A. Purchasing behaviour for environmentally sustainable products: A conceptual framework and empirical study. J. Retail. Consum. Serv. 2017, 34, 1-9. [CrossRef]

37. Liere, K.D.V.; Dunlap, R.E. The social bases of environmental concern: A review of hypotheses, explanations and empirical evidence. Public Opin. Q. 1980, 44, 181-197. [CrossRef]

38. Taufique, K.M.R.; Vaithianathan, S. A fresh look at understanding green consumer behavior among young urban indian consumers through the lens of theory of planned behavior. J. Clean. Prod. 2018, 183, 46-55. [CrossRef]

39. Hume, M. Compassion without action: Examining the young consumers consumption and attitude to sustainable consumption. J. World Bus. 2010, 45, 385-394. [CrossRef]

40. Verma, V.K.; Chandra, B. An application of theory of planned behavior to predict young indian consumers' green hotel visit intention. J. Clean. Prod. 2018, 172, 1152-1162. [CrossRef]

41. Reddy, S.; Painuly, J.P. Diffusion of renewable energy technologies-Barriers and stakeholders' perspectives. Renew. Energy 2004, 29, 1431-1447. [CrossRef]

42. Kaman, L. Opportunities for green marketing: Young consumers. Market. Intell. Plan. 2008, 26, 573-586.

43. Diamantopoulos, A.; Schlegelmilch, B.B.; Sinkovics, R.R.; Bohlen, G.M. Can socio-demographics still play a role in profiling green consumers? A review of the evidence and an empirical investigation. J. Bus. Res. 2003, 56, 465-480. [CrossRef]

44. Hartmann, P.; Apaolaza-Ibáñez, V. Consumer attitude and purchase intention toward green energy brands: The roles of psychological benefits and environmental concern. J. Bus. Res. 2012, 65, 1254-1263. [CrossRef]

45. Mostafa, M.M. A hierarchical analysis of the green consciousness of the egyptian consumer. Psychol. Market. 2007, 24, 445-473. [CrossRef]

46. Qian, Q.; Chan, E.; Khalid, A. Challenges in delivering green building projects: Unearthing the transaction costs (tcs). Sustainability 2015, 7, 3615-3636. [CrossRef]

47. Gou, Z.; Lau, S.S.-Y.; Prasad, D. Market readiness and policy implications for green buildings: Case study from hong kong. J. Green Build. 2013, 8, 162-173. [CrossRef]

48. Paul, J.; Modi, A.; Patel, J. Predicting green product consumption using theory of planned behavior and reasoned action. J. Retail. Consum. Serv. 2016, 29, 123-134. [CrossRef]

49. Liobikienè, G.; Mandravickaite, J.; Bernatonienė, J. Theory of planned behavior approach to understand the green purchasing behavior in the eu: A cross-cultural study. Ecol. Econ. 2016, 125, 38-46. [CrossRef]

50. Armitage, C.J.; Conner, M. Efficacy of the theory of planned behaviour: A meta-analytic review. Br. J. Soc. Psychol. 2001, 40, 471-499. [CrossRef] [PubMed]

51. Kim, Y.; Han, H. Intention to pay conventional-hotel prices at a green hotel-A modification of the theory of planned behavior. J. Sustain. Tour. 2010, 18, 997-1014. [CrossRef]

52. Zimmer, M.R.; Stafford, T.F.; Stafford, M.R. Green issues: Dimensions of environmental concern. J. Bus. Res. 1994, 30, 63-74. [CrossRef]

53. Huang, H. Study on the Influence Factors of Willingness to Pay for Green House in Lanzhou City; Lanzhou Jiaotong University: Lanzhou, China, 2014. (In Chinese)

54. Nurul Diyana, A.; Zainul Abidin, N. Motivation and expectation of developers on green construction: A conceptual view. Int. Sch. Sci. Res. Innov. 2013, 7, 914-918.

55. Zhang, L.; Li, Q.; Zhou, J. Critical factors of low-carbon building development in china's urban area. J. Clean. Prod. 2017, 142, 3075-3082. [CrossRef]

56. Group Building Map. Available online: http://www.gbmap.org/ (accessed on 10 December 2017).

57. Kline, R.B. Principles and practice of structural equation modeling. J. Am. Stat. Assoc. 2011, 101, 427. 
58. Hair, J.; Anderson, R.; Tatham, R.; Black, W.C.A. Multivariate Data Analysis; Pearson Education: Upper Saddle River, NJ, USA, 1998.

59. Fornell, C.; Larcker, D.F. Evaluating structural equation models with unobservable variables and measurement error. J. Market. Res. 1981, 18, 39-50. [CrossRef]

60. Chin, W.W.; Gopal, A.; Salisbury, W.D. Advancing the theory of adaptive structuration: The development of a scale to measure faithfulness of appropriation. Inf. Syst. Res. 1997, 8, 342-367. [CrossRef]

61. Brown, T.A. Confirmatory Factor Analysis for Applied Research; Guilford: New York, NY, USA, 2006.

62. Chen, M.-F.; Tung, P.-J. Developing an extended theory of planned behavior model to predict consumers' intention to visit green hotels. Int. J. Hosp. Manag. 2014, 36, 221-230. [CrossRef]

63. Tan, C.-S.; Ooi, H.-Y.; Goh, Y.-N. A moral extension of the theory of planned behavior to predict consumers' purchase intention for energy-efficient household appliances in malaysia. Energy Policy 2017, 107, 459-471. [CrossRef]

64. Yadav, R.; Pathak, G.S. Determinants of consumers' green purchase behavior in a developing nation: Applying and extending the theory of planned behavior. Ecol. Econ. 2017, 134, 114-122. [CrossRef]

65. Greaves, M.; Zibarras, L.D.; Stride, C. Using the theory of planned behavior to explore environmental behavioral intentions in the workplace. J. Environ. Psychol. 2013, 34, 109-120. [CrossRef]

66. Zuo, J.; Zhao, Z.-Y. Green building research-current status and future agenda: A review. Renew. Sustain. Energy Rev. 2014, 30, 271-281. [CrossRef]

67. Shi, Q.; Yu, T.; Zuo, J. What leads to low-carbon buildings? A china study. Renew. Sustain. Energy Rev. 2015, 50, 726-734. [CrossRef]

68. An Ju Ke. Available online: https://jinan.anjuke.com/market/ (accessed on 14 March 2018).

69. Xu, Z. Introduction of incentive policies for green buildings and promotion proposals in Chinese 13th five-year plan. J. Build. 2016, 7, 9-17. (In Chinese)

70. Yau, Y.; Chiu, S.M.; Lau, W.K. Economising subsidies for green housing features: A stated preference approach. Urbani Izziv 2014, 25, 107-118. [CrossRef]

71. Albayrak, T.; Aksoy, Ş.; Caber, M. The effect of environmental concern and scepticism on green purchase behaviour. Market. Intell. Plan. 2013, 31, 27-39. [CrossRef]

72. Zuo, J.; Xia, B.; Barker, J.; Skitmore, M. Green buildings for greying people. Facilities 2014, 32, $365-381$. [CrossRef]

73. Attaran, S.; Celik, B.G. Students' environmental responsibility and their willingness to pay for green buildings. Int. J. Sustain. Higher Educ. 2015, 16, 327-340. [CrossRef]

74. Echegaray, F.; Hansstein, F.V. Assessing the intention-behavior gap in electronic waste recycling: The case of brazil. J. Clean. Prod. 2017, 142, 180-190. [CrossRef]

75. Hai, M.A.; Moula, M.M.E.; Seppälä, U. Results of intention-behaviour gap for solar energy in regular residential buildings in finland. Int. J. Sustain. Built Environ. 2017, 6, 317-329. [CrossRef] 